\title{
Socioeconomic and competitive positioning of livestock chains in Zacatecas, Mexico
}

Sánchez-Toledano, Blanca ${ }^{1}$, Zegbe, Jorge A. ${ }^{1}$, Cuevas-Reyes, Venancio ${ }^{2 *}$

${ }^{1}$ Campo Experimental Zacatecas-INIFAP. Calera de Victor Rosales, Zacatecas, México. ${ }^{2}$ Campo Experimental Valle de México-INIFAP. Coatlinchán, Texcoco, Estado de México.

${ }^{*}$ Corresponding author: cuevas.venancio@agmail.com

\begin{abstract}
Objective: To determine the positioning of the most important livestock production chains in Zacatecas, Mexico, within a matrix of socioeconomic importance and market competitiveness, and to identify research and technology transfer needs.

Design/Methodology/Approach: Arranging livestock production chains into a hierarchy was carried out based on the methodology proposed by the International Service for National Agricultural Research (ISNAR), taking as analysis axis the dimensions of socioeconomic importance and competitiveness. The six most outstanding livestock production chains in the state were selected.

Results: The results placed the beef cattle chains as sustainable, the goat and sheep chains were placed as vulnerable, pork and honey were located in the retraction quadrant due to their low socioeconomic importance and competitiveness, and dairy cattle was placed in the strained quadrant.

Study Limitations/Implications: It is important to take into account other links.

Findings/Conclusions: Strategies for livestock production chains involve making the production more efficient through sustainable practices, providing technical assistance to producers, conducting research to generate technology, investing in infrastructure, and generating products with added value that meet the needs of consumers.
\end{abstract}

Keywords: Production chains, indicators, technologies.

\section{INTRODUCTION}

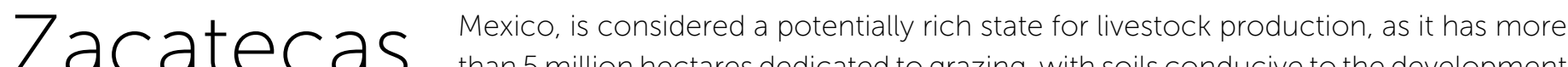

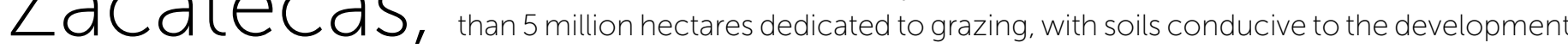
of good quality pastures and native grasses (Poaceae) of high forage value (Sánchez et al., 2015). The livestock sector in the state of Zacatecas generated a production value equal to 5.6 million pesos during 2017, within which beef cattle production accounted for $56 \%$ of the state production value with a contribution of $\$ 3.1$ million pesos, through the production of 45,501 tons of meat. The second place was occupied by the dairy subsector, with $19.4 \%$ which generated $\$ 1.1$ million pesos from the commercialization of 186,483 of liters of milk (SIAP, 2017).

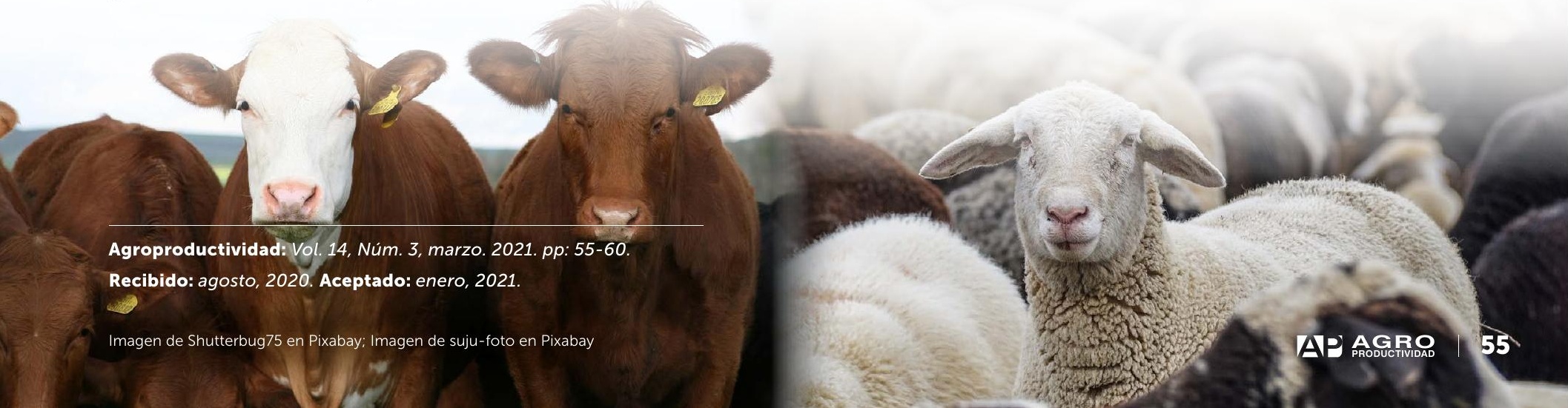


Livestock activities in the state represent a source of employment and income for the rural population. However, in order to improve productivity and quality to meet the demands of domestic and international markets, it is imperative to adapt and adopt technological changes and, therefore, optimize competitiveness. To achieve competitiveness in agrifood chains, the sector must design sectoral regulations that take into account not only the links involved in production, but also the options for specialization and interactions between production and the environment (Díaz and Hartley, 2006). To study the differentiated competitiveness of agricultural systems-products, the analysis of agricultural chains has been suggested (Antúnez and Ferrer, 2016).

Research on agro competitiveness and socioeconomic importance has been conducted in the state of Zacatecas (Sánchez et al., 2013; Rincón et al., 2004). However, the dynamism of production chains requires continuous monitoring, and previous studies have not focused on livestock production chains. Therefore, the objective of this study was to determine the positioning of the most important livestock production chains in Zacatecas, within a matrix of socioeconomic importance and market competitiveness, and to identify research and technology transfer needs. The information generated by this type of study will help decision-makers to efficiently direct financial, technological and research resources to each of the production chains.

\section{MATERIALS AND METHODS}

The study was carried out in 2019 in Zacatecas, Mexico, with the search of secondary information through the Service for Agrifood and Fishery Information (Servicio de Información Agroalimentaria y Pesquera, SIAP, 2017). A total of six livestock production chains were included, which were defined according to their economic and social importance in the state. The methodology does not consider a static point, but rather the trend over the last five years.

The methodology proposed by the International Service for National Agricultural Research (ISNAR) (Pardey and Roseboom, 2004) was used to rank the livestock production chains in Zacatecas according to weighted criteria, in order to identify strategic production chains through dimensionless values. Two guidelines were considered for this study: a) the socioeconomic relevance of the production chains; in other words, this axis considered attributes that justified the productive activity of each chain, due to their relevance; and b) competitiveness, which is an axis that explains the capacity of those involved in a production chain to face the challenges of change and their ability to adapt and overcome them.

To analyze socioeconomic importance, the following indicators were considered: a) Size: this concept refers to the dimension of the livestock production chain in terms of production value and contribution to the state's economy; the area occupied by the number of heads of livestock species and the number of day laborers required for the activity were estimated; b) Dynamism: it represents the trend of production value and was presented with a simple linear regression for each chain. The slope indicated the rate of change of prices per unit of time. This section also evaluated the evolution of real prices by calculating the mean and standard deviation of the last five years, as well as the slope of the jobs produced in the state by the production chain; c) Specialization: it identified the level of specialization and economic concentration.

Competitiveness was studied using the following parameters: a) Productivity: this was based on three items: 1) relative productivity: [(state yield per chain)/ (national yield per chain)] and 2) labor productivity, which was estimated by dividing the cost invested in wages by gross income; b) Sustainability: it considers soil erosion estimated from the universal soil loss equation (USLE) (Wischmeier and Smith, 1978), in this case the mean state erosion value per chain was used. Similarly, water efficiency and contamination from the use of fertilizers were analyzed, and for these sections a group of expert researchers (18 individuals) was formed to evaluate both aspects; c) Commercial performance: this variable was estimated based on the trend of real prices, which were obtained through the slope of the simple linear regression model of the price values (this value was considered as the exchange rate per unit of time).

All criteria or variables were standardized to zero mean and standard deviation of one, in order to have variables with equal magnitude and units (standard deviations) (Sanchez et al., 2013). Thus, the positioning matrix with the two reference axes, weighted and accumulated, was obtained. The results generated by the standardized matrix were presented as an interaction between the axes of a graph with four quadrants that indicate the positioning of each of the production chains (Jolalpa et 
al., 2010). The data were analyzed with the Microsoft Excel software.

\section{RESULTS AND DISCUSSION}

It was found that there are six major livestock production chains in Zacatecas, so they were prioritized. Analysis of the information made it possible to rank the livestock chains according to the sum of all their indicators, their relative value and their hierarchy. The results indicated that the most important production chain was dairy cattle, followed by beef cattle, sheep, goats, honey and pork (Table 1).

Integration of the information made it possible to locate the livestock production chains in the positioning matrix, which formed four groups according to the socioeconomic relevance and competitiveness of each chain in the state of Zacatecas (Figure 1).

In 2013, the beef cattle chain ranked 0.7 in competitiveness and 1.7 in socioeconomic importance; six years later, this chain ranked 1.1 and 0.4 in competitiveness and socioeconomic importance, respectively. This showed that beef cattle decreased in competitiveness, but increased its socioeconomic importance. Nevertheless, this chain obtained the greatest socioeconomic and competitive importance (Figure 1, Quadrant I). This was sustained in the 20152016 cycle, where 31,769 head were exported; with this, the state ranked sixth nationally in live cattle exports to

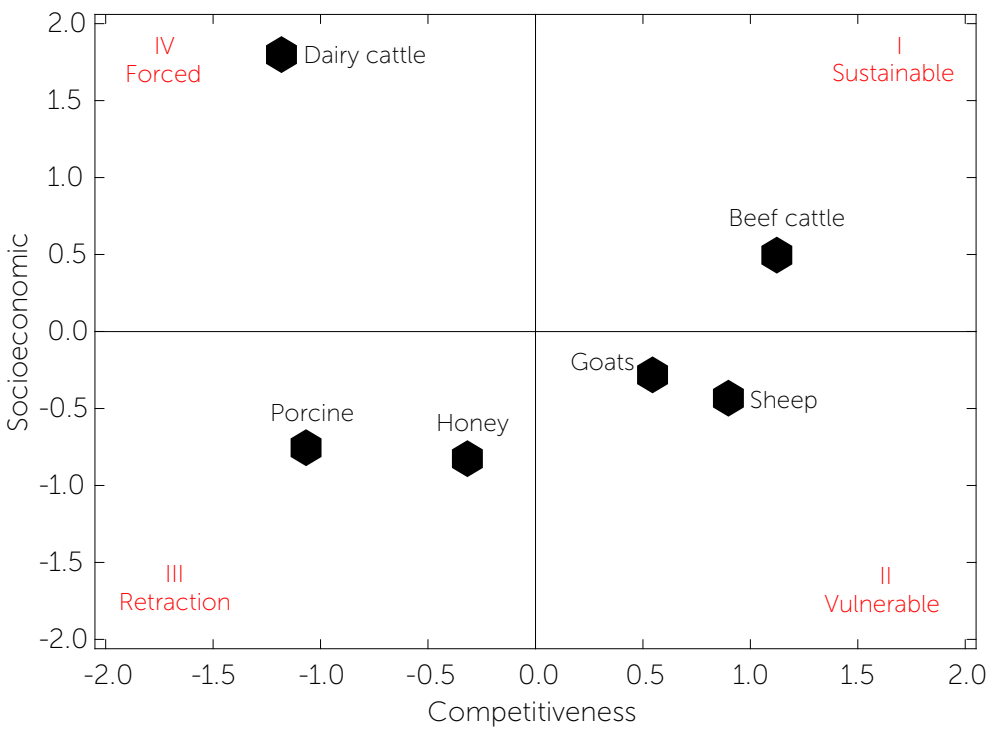

Figure 1. Bi-dimensional positioning for the livestock production chains Experimental Station of Zacatecas, 2019 the United States (FAOSTAT, 2017). However, for this chain to continue to be sustainable, it is imperative to guarantee safety and to produce excellent quality meat in the shortest possible time, in order for the livestock enterprise to be efficient and profitable. In terms of the international market, quality is considered to be that which contains high muscle content and sufficient intramuscular fat (marbling) to satisfy the organoleptic requirements of the consumer (Monsón et al., 2005).

At the same time, all market segments must be taken into account, for which one of the options is to opt for the minimum processing of the product (from live animals to meat cuts). With the minimum process, the profitability of the farmer increases, since the price received per standing calf is $\$ 28$ per $\mathrm{kg}$ and up to $\$ 40$ per $\mathrm{kg}$ of bull calf; while the average price per cut varies between $\$ 90$ and $\$ 140$ per $\mathrm{kg}$ of meat (SNIIM, 2019), which means $250 \%$ increase. This explains that much of the price is generated within the commercialization process through minimal processing of the product (from live animals to meat cuts), transportation (from the production area to the consumption centers), and from there to international distribution.

It is also necessary for farmers to become involved in the commercial process in order to reduce the number of intermediaries involved in the chain. Studies indicate that, from calf collection to the final consumer, there are between 5 and 10 links in the chain; and, depending on the flowchart of the chain, the participation time for each agent varies from one day (stockers, wholesalers and slaughterers) to four to eighteen months (fatteners and breeders) (Licea et al., 2015).

Market opportunities for this chain in Mexico are high, despite the fact that beef consumption has declined, but its nutritional and economic 
importance is high; in 2000 more than 22 kg per capita were consumed, but in 2016 there was a significant decrease (14.9 kg per capita) (SIAP, 2017). This reduction in consumption was due to the sustained increase in per capita consumption of chicken meat (29.2 per capita) (SIAP, 2017), and the recovery in pork consumption (16.6 kg per capita) (SIAP, 2017). Consequently, marketing strategies must be implemented to maintain and promote the positioning of the beef cattle production chain.

At the reproductive level, farmers in the region must pay attention to improving the genetic quality of cattle to obtain better yields. Genetic improvement through the acquisition of registered sires is vital to increase the quality and productivity of cattle herds and, therefore, to achieve a significant improvement in the technical and economic parameters of the activity (Carrera, 2008).

The goat and sheep chains are in the vulnerable quadrant (Figure 1, Quadrant II). In 2019, these production chains were competitive, but they require greater social and economic importance. The negative values in the socioeconomic axis are due to the low number of heads per herd, the decrease in the production value, and the few day laborers used to carry out productive activities. Low precipitation in Zacatecas (less than $400 \mathrm{~mm}$ in some areas) has reduced crop productivity and the availability of grass forage which has led to a decrease in the herd (Echavarría et al., 2014). Despite this, the momentum of these chains is preponderant as it contributes to the survival of low-income producers, providing food and income (Echavarría et al., 2015). Therefore, in order to move these production chains from a state of impulse to one of high strategic priority, technology transfer projects must be implemented to reduce the seasonality of reproduction, since the offspring are born in late winter and early spring, when the highest end-of-year market demand has already passed; this decreases profits and is the longest period of drought, which reduces the availability of grasses, leading to increased mortality rates or low development rates. Thus, it is necessary to breed at times that guarantee births at the beginning of the rainy season, that is, to change the reproductive cycle (López et al., 2011).

Likewise, it is necessary to develop abilities in farmers to improve management practices (Salinas and Rumayor, 1999) and reduce animal health problems (Echavarría et al., 2010). Similarly, it is imperative to add value to primary production and to focus products on specialized segments. Segmentation allows producers to avoid head-on competition in the market by differentiating offers, not only on the basis of price but also in terms of product characteristics, advertising messages, and distribution methods (Fernández and Aqueveque, 2001).

In 2019, the pork and honey production chains were positioned in quadrant III, with low socioeconomic importance and low competitiveness in the state context. These chains have been introduced recently to the State, and were characterized by low dynamism and innovation, low pay for workers, and a marked inability to generate jobs. From 2013 to 2019 these chains dropped from quadrant II to quadrant III (Figure 1). The change in dynamism of the pork and beekeeping sectors (vulnerable quadrant to retraction quadrant) in this region was due to a combination of various factors specific to the state and the macroeconomic and sectoral policies adopted by Mexico as a result of trade liberalization. This had an impact on the development of the agricultural sector, especially the pork production sector. The withdrawal of government subsidies to pig farmers caused a decrease in the activity by consolidating the most efficient companies and eliminating the semi-technified ones (García et al., 2004). This event generated variations in pork production growth rates and different effects among the country's regions. Thus, the pork production chain in the state remained a slow-growing activity, because of inefficient use of resources, low productivity and a low degree of technification; this led to it being classified as a lagging region (Rebollar et al., 2015). The strategy should be to increase technical assistance in terms of health, nutrition, vaccination and biosecurity programs, and to improve infrastructure and seek alternative marketing channels.

The beekeeping chain in Zacatecas has low production $(2,077 \mathrm{t})$, but stands out nationally for its quality and amber color. The honey commercialization process in the state is carried out directly by the beekeeper or family members and is packaged in containers with many presentations. Among the factors that influenced its low production are the indiscriminate use of pesticides, high feed costs, poor genetic quality of queen bees and weather conditions, particularly the drought in 2011, which worsened in 2012, resulting in low flora, water scarcity and death due to hypothermia and diseases that attack the insect (Secretaría del Campo, 2018). 
The importance of pollinating insects in global food production is undisputed, and it can be argued that it will become increasingly important in a context of increasing food production needs and declining pollinators, especially the domestic honeybee (Miñarro et al., 2018).

Sustainable agricultural practices, and in particular agroecology, can help protect bees by reducing exposure to pesticides and helping to diversify agricultural landscapes (FAO, 2017). Consequently, the strategy for this chain includes projects that promote bee health, technology transfer to increase productivity and safety, pesticides and practices that help reduce the exposure of pollinators, as well as research and investment in infrastructure.

The dairy cattle chain in 2013 was positioned at -1.9 and 0.5 in competitive and socioeconomic circumstances, and six years later this chain is positioned at -1.1 and 1.7 respectively. Consequently, this chain improved in terms of socioeconomic importance, but declined 0.8 in competitiveness. The dairy cattle chain is in a strained state (Figure 1, Quadrant IV), that is, it has high socioeconomic importance but lacks competitiveness in the state context. The weaknesses faced by the dairy cattle chain are reduced sustainability due to the amount of water for fodder production, commercial performance and labor productivity. The strength of this chain is its dynamism and specialization, in addition to the fact that it is the chain with greatest social weight (high number of rural production units, production value and jobs generated).

The permanence of the dairy cattle chain in the region is explained by the dynamics of intensive livestock production in the Comarca Lagunera (Coahuila and Durango). However, milk production in Zacatecas is losing importance, mainly due to the effects of recurrent drought in recent years, which has made forage more expensive, making the activity less profitable and leading producers to sell or slaughter their cattle (Sánchez et al., 2015). Therefore, in order for this chain to change from a state of maintenance to one of high strategic priority, projects aimed at promoting the organization of production, financing, investment in technology, efficient commercialization channels and technical assistance must be implemented. In addition, the availability of forage alternatives that allow increasing productivity in the use of water; that is, reducing the amount of water to produce one $\mathrm{kg}$ of forage with high nutritional value. Support for small producers by government institutions is necessary because it has been concentrated in vertically integrated producer groups that collect, add value, and market both milk and its byproducts. However, it is important to mention that, in the state of Zacatecas, production is located in the semi-arid-temperate region, and is characterized as a family dairy system.

Innovations related to feeding, milk quality, genetics and technical assistance are the most relevant in the family dairy production system. In family systems, feeding is the main cost of production, but at the same time, if it is done properly, it represents an opportunity; silage feeding allows sustaining livestock production throughout the year, avoids the seasonality of milk production, reduces losses caused by poor feeding, and increases milk production and profitability (Raymond et al., 1989).

\section{CONCLUSIONS}

The strategic positioning of the chains indicated that the beef cattle chain was sustainable, the goat and sheep chains were vulnerable, the pork and honey chains were in retraction due to their low socioeconomic importance and competitiveness, and the dairy cattle chain was a strained chain. The strategies for livestock production chains are to be efficient in production through sustainable practices, to provide technical assistance to producers, to conduct research to generate technology, to invest in infrastructure, to generate value-added products that meet the needs of consumers, and to seek short commercialization channels.

\section{REFERENCES}

Antúnez, S. I. y Ferrer, C. M. (2016). El Enfoque de cadenas productivas y la planificación estratégica como herramientas para el desarrollo sostenible en Cuba. RIPS. Revista de Investigaciones Políticas y Sociológicas. 15(2):99-130. doi.org/10.15304/ rips.15.2.3383

Carrera, C. B. (2008). La ovinocultura en México: ¿alternativa para los productores rurales? UACJ. Avances Cuadernos de Trabajo. 207: 1-17.

Díaz, R. y Hartley, M. (2006). Evaluación del ciclo de vida aplicada en agrocadenas productivas: un instrumento de gestión ambiental para el diseño de políticas. Revista Iberoamericana de Economía Eet alógica. 3: 1-15.

Echavarría, Ch. F., Santos de la Cruz, J., Gutiérrez, G. R. y Medina, G. G. (2015). Validación de una estrategia metodológica para la evaluación cualitativa de un pastizal mediano abierto del estado de Zacatecas. Revista mexicana de ciencias pecuarias. 6(2): 171-191. doi.org/10.22319/rmcp.v6i2.4061. 
Echavarría, Ch. F., Serna, P. A., Flores, N. M., Medida, G. G., Gutiérrez, L. R., Salinas, G. H. y López, G. J. (2014). Sistema de producción de forrajes de temporal una opción para la reconversión productiva. CIRNOC- INIFAP. Folleto Técnico No.53.

Echavarría, Ch. F., Serna, P. A., Salinas, G. H., Iniguez, R. L. y Palacios, D. M. (2010). Small rumiant impacts on rangelands of semiarid highlands of México and the reconverting by grazing sistemas Small Ruminant Research. 89(29): 211-217. doi.org/10.1016/j. smallrumres.2009.12.046

Echavarría, Ch. F., Serna, P. A., Rubio, A. F., Rumayor, R. A. y Salinas, G. H. (2009). Productividad del chamizo Atriplex canescens con fines de reconversión: dos casos. Revista Mexicana de Ciencias Pecuarias. 47(1): 93-106

Fernández, R. C. y Aqueveque, T. C. (2001). Segmentación de mercados: buscando la correlación entre variables siet alógicas y demográficas. Revista et alombiana de Marketing. 2(2):1-14.

FAO. (2017). El estado de la seguridad alimentaria y la nutrición en el mundo 2017. Fomentando la resiliencia en aras de la paz y la seguridad alimentaria. Roma: Disponible en https://www.fao. org. Acceso marzo 13, 2019.

FAOSTAT. (2017). Organización de las naciones unidas para la alimentación y la agricultura (FAO). http://faostat.fao.org Acceso enero 10, 2019.

García, M. R., Del villar, V. M. y García, S. A. (2004). Modelo econométrico para determinar los factores que afectan el mercado de la carne de porcino en México. Interciencia. 29: 414-420

Jolalpa, J., Moctezuma, G., González, A. y Pérez, M. (2010). Determinación de las principales cadenas productivas en el sector agriet ala, pecuario y forestal en el estado de México. In Memoria del XXIII Congreso Internacional de Administración de Empresas Agropecuarias, San Luis Potosí, México pp 51-56.

Licea, G. R., Alvarado, J. G. y Guzmán, J. L. (2015). Ventajas regionales de diferenciación de la cadena de valor de carne de bovino en México. Revista Raites. 1(2): 81-103.

López, G. J., Fuentes, B., H., Serna, P. A., Sánchez, G. R., Figueroa, G. J., Servín, P. M., Echavarría, Ch. F. y Salinas, G. H. (2011). La interacción de un macho cabrío sexualmente activo con un tratamiento fotoperiódico reduce la estacionalidad en cabras anéstricas. CIRNOC-INIFAP. Folleto Técnico No. 36

Miñarro, M., García, D. y Martínez, R. (2018). Los insectos polinizadores en la agricultura: importancia y gestión de su biodiversidad. Ecosistemas. 27(2): 81-90. Doi.: 10.7818/ECOS.1394.

Monsón, F., Sañudo, C. y Sierra, I. (2005). Influence of breed and ageing time on the sensory meat quality and consumer acceptability in intensively reared beef. Meat Sci. 71: 471-479. doi.org/10.1016/j. meatsci.2005.04.026.

Pardey, P. G. y Roseboom, J. (2004). ISNAR agricultural research indicator series: A global data base on national agricultural research systems. Cambridge University Press.

Raymond, F., Redman, P. y Wlatha, R. (1989). Forages Conservation and Feeding. 4 ed. Farming Press LTD, Inglaterra.188 p.

Rebollar, R. A., Rebollar, R. S., Gómez, T. G., Hernández, M. J. y González, R. F. (2016). Crecimiento y especialización regional del sector pecuario en México, 1994 a 2013. Revista Mexicana de Ciencias Pecuarias. 7(3): 391-403. doi.org/10.22319/rmcp. v7i3.4217.

Rebollar, R. A., Gómez, T. G., Rebollar, R. S., Hernández, M. J. y González, R. D. (2015). Dinámica regional de la producción porcina en México, 1994-2012. Agrociencia. (49):455-473.

Rincón, F., Echavarría, F., Rumayor, A., Mena, J., Bravo, A., Acosta, E., Gallo, J. y Salinas, H. (2004). Cadenas de Sistemas Agroalimentarios de Chile Seco, Durazno y Frijol en el Estado de Zacatecas: una aplicación de la Metodología ISNAR. INIFAP. CIRNOC. Campo Experimental Zacatecas. Publicación

Salinas, G. H. y Rumayor, R. A. (1999). A whole-farm model for economics anlalysis in a goat production sistema in México. Small ruminant Research. 31:157-164. doi.org/10.1016/s09214488(98)00126-6.

Sánchez, G. R., Zegbe, D. J. y Gutiérrez, B. H. (2015). Tipificación de un sistema integral de lechería familiar en Zacatecas, México. Revista Mexicana de Ciencias Pecuarias. 6(3): 349-359. doi. org/10.22319/rmcp.v6i3.4097

Sánchez-Toledano, B., Zegbe, D. J. y Rumayor, R. A. (2013). Moctezuma LG. Estructura económica competitiva del sector agropecuario de Zacatecas: Un análisis por agrocadenas. Revista Mexicana de Agronegocios. 33 (2): 552-563.

Servicio de Información Agroalimentaria y Pesquera (SIAP). (2017). Atlas Agroalimentario. Disponible en https://www.gob.mx/siap/ prensa/atlas-agroalimentario-2017. Acceso febrero 10, 2019.

Secretaría del Campo del Gobierno. (2018). Condiciones climáticas en Zacatecas. Disponible en: http://secampo.zacatecas.gob.mx/ oficial/. Acceso junio 10, 2019.

Sistema de nacional de información de mercados (SNIIM). (2019). Precio de mercado pecuarios. Disponible en: http://www. economia-sniim.gob.mx/nuevo. Acceso mayo 10, 2019

Wischmeier, H. y Smith, D. (1978). Predicting rainfall erosion losses. A guide to conservation planning. USDA Agric. Handbook. 357 p. 